\title{
The Correlation between Penetration Pressure Required to Install Pile Foundation and to Insert Bi-cones In Cone Penetration Test
}

\author{
Budi, G. S. ${ }^{*}$, Tandiputra, A. G. ${ }^{2}$, and Markho, H. K. ${ }^{3}$
}

\begin{abstract}
One of the common methods used to install pile foundation is hydraulic jacked-in machine. In this method, a pile is pushed down into the ground up to the predetermined depth. The method has similar principle to that of Cone Penetration Test (CPT). This paper presents the correlation between the mobilize pressure required to install pile foundations and that required to push the bi-cones that attached at the tip of CPT rod. The results show that the penetration pressure required to install the pile into very soft clay layer is independent of pile diameter. The penetration pressure required to install the pile into soft to stiff clay layers depends on the pile diameter. The larger the diameter of piles, the smaller the penetration pressures required. The penetration pressure required to install the pile into stiff expansive clay layer beyond the depth of active zone can be predicted as high as the pressure calculated form CPT.
\end{abstract}

Keywords: CPT, Jacked-in pile, mobilize pressure.

\section{Introduction}

Cone penetration test (CPT) is a field soil investigation technique, which formerly called Barentsenapparatus, was developed initially in 1932. The apparatus was named after Pieter Barentsen, who performed the first CPT for a road around Gouda in The Netherland. In 1965, H.K.S.Ph. Begemann built mechanical friction jacket cone to equip the Barentsen-apparatus so that it named Begemann cone [1]. Cone Penetration Test is a device to measure the point bearing and friction resistances of soil. These soil capacities are measured by mean of pushing steel rod that equipped with a device called bi-cones at its tip. The end bearing and sleeve resistances are called cone resistance (qc) and friction (fs), respectively. These resistances, in fact, are in the state of mobilize condition, since the data is recorded during the bi-cones is being pushed down into the soil.

Hydraulically jacked-in pile system is a method of installing pile foundation by means of pushing a pile into the ground. The system is also known as silent piler since there is no vibration and noise generated during the process of pile installation. The applied jacking-pressure to install a pile can be monitored and recorded at any depth along the pile. In other words, the recorded jacking-pressure represents the mobilize resistance of the installed pile.

1,2,3 Department of Civil Engineering, Faculty of Civil Engineering and Planning, Petra Christian University, Jl. Siwalankerto 121131, Surabaya 60236, INDONESIA

*Corresponding author; email: gogot@petra.ac.id

Note: Discussion is expected before June, $1^{\text {st }} 2019$, and will be published in the "Civil Engineering Dimension", volume 21, number 2, September 2019 .

Received 13 March 2019 revised 15 March 2019; accepted 19 March 2019
White and Deeks [2] stated that the jacking-pressure to install a pile can be compared to that to insert a bicones in CPT since both of them have similar principle of works. Lehane et al. [3] stated that the cone resistance (qc) of CPT is about $80 \%$ of the jacking-pressure required to install a pile. Mahler [4] compared bearing capacity of pile foundation, which was determined from Static Load Test data to that calculated theoretically using DIN 4014 method [5], Bustamante and Gianeselli method [6], Eurocode 7-3 method [7], and ERTC3 method [8]. The investigated piles were Continuous Flight Auger (CFA) with diameter varied from $0.60 \mathrm{~m}$ to $1.00 \mathrm{~m}$, which were installed in different soil conditions. It was reported that the predicted bearing capacity of pile was overestimated, compared to that determined from Static Load test data.

$\mathrm{Hu}$ et al. [9] conducted research about the set-up development of $300 \mathrm{~mm}$ diameter of steel pipe jacked-in piles correlated to a CPT, which was equipped with auxiliary sensor to measure the actual total shaft resistance. It was reported that there were three types of correlations between measured shaft resistance and that calculated using CPT data. Those types were grouped into three categories that include 'weaken-type', 'close-type', and 'strengthen-type'. When the measured shaft resistance of a pile is close to the calculated one, it was called close-type. The weaken-type and strengthentype were defined as the state, where the measured shaft resistance of a pile is less than and larger than that of calculated shaft resistance, respectively.

The aforementioned research mainly focused on the bearing capacity of non-displacement piles (CFA) installed in different soil conditions, which was determined from static load tests and that from 
predicted using several methods. While research performed by $\mathrm{Hu}$ et al. [9] employed single pile diameter only. This research was conducted to get better understanding of the relationship between pressure calculated from CPT and that required to install spun piles in different soil conditions, using jacked-in method. The diameter used in the research was $250 \mathrm{~mm}, 500 \mathrm{~mm}$, and $600 \mathrm{~mm}$.

The purpose of this research is thus to study the correlation between penetration pressure recorded from the jacked-in machine during the installation of spun piles with different diameter and that calculated analytically from cone penetration test (CPT) data.

\section{Research Method}

Pile dimension used in the research ranging from $250 \mathrm{~mm}$ to $600 \mathrm{~mm}$. The data was collected from three different projects. Soil types in the area of the projects were dominated by clay layers that include expansive clay, very soft clay, and stiff clay.

\section{Cone and Friction Resistance}

The pressure of cone penetration test (CPT) can be calculated from the data of cone resistance (qc) and friction resistance (fs) at any depth, or can also be recorded directly from the readings during testing. The penetration pressure can be calculated from cone and friction resistances, as follows [10]:

$$
\begin{aligned}
& \mathrm{Cw}=\frac{q c \times A c}{A p i} \\
& (\mathrm{Tw}-\mathrm{Cw})=\frac{f s \times A s}{A p i}
\end{aligned}
$$

Where:

$\mathrm{Cw}$ : recorded pressure to push the tip of the bicones $\left(\mathrm{kg} / \mathrm{cm}^{2}\right)$;

Tw : recorded total pressure to push both the tip and shaft friction of the bi-cones $\left(\mathrm{kg} / \mathrm{cm}^{2}\right)$;

$q c \quad$ : cone resistance $\left(\mathrm{kg} / \mathrm{cm}^{2}\right)$;

$f_{s} \quad$ : side friction resistance $\left(\mathrm{kg} / \mathrm{cm}^{2}\right)$;

Api : cross section area of the piston $\left(\mathrm{cm}^{2}\right)$;

Ac : cross section of the bi-cones $\left(\mathrm{cm}^{2}\right)$;

As : surface area of the side friction (shaft) of the bi-cones $\left(\mathrm{cm}^{2}\right)$;

Based on the aforementioned equations, the total pressure required to penetrate a bi-cones can be obtained either from the records of total applied pressure (Tw) or by formula.

While the total pressure required to install a pile was recorded directly from the pressure indicator located in the operation room of the jacking machine or obtained by dividing load required to install a pile by its cross section area.
Data of the research was collected from three different projects. The information regarding the projects is presented in Table 1.

Tabel 1. Description of the Research Projects

\begin{tabular}{ccccc}
\hline Projects & $\begin{array}{c}\text { Pile } \\
\text { dimension } \\
(\mathrm{mm})\end{array}$ & $\begin{array}{c}\text { Number of } \\
\text { CPT }\end{array}$ & $\begin{array}{c}\text { Number } \\
\text { of jacked- } \\
\text { in piles }\end{array}$ & $\begin{array}{c}\text { Depth of } \\
\text { CPT (m) }\end{array}$ \\
\hline \multirow{2}{*}{ A } & Dia. 250 & 8 & 10 & 15 \\
& Dia. 500 & $\begin{array}{c}8 \\
\text { (Clay) }\end{array}$ & 10 & 27 \\
Dia. 600 & Dia. 500 & $\begin{array}{c}3 \\
\text { B }\end{array}$ & 10 & 27 \\
\hline C & Dia. 500 & $\begin{array}{c}4 \\
\text { (expansive clay) }\end{array}$ & 15 & 12 \\
\hline
\end{tabular}

\section{The Effect of Pile Diameter}

The correlation between penetration pressure obtained from CPT data and that from jacked-in machine for piles with diameter of $250 \mathrm{~mm}, 500 \mathrm{~mm}$, and $600 \mathrm{~mm}$ is presented on Figure 1, Figure 2, and Figure 3, respectively. It can be observed that almost all pressures required to penetrate the piles with diameter of $250 \mathrm{~mm}$ (Figure 1) are inside the range of the penetration pressures recorded from CPT. Adopting the criterion stated by $\mathrm{Hu}$ et al. [9], this condition can be categorized as close-type. While Figure 2 and Figure 3 show that the penetration pressures to install the piles with diameter $500 \mathrm{~mm}$ and $600 \mathrm{~mm}$ are smaller than those calculated from CPT or defined as weaken-type.

The discrepancy of penetration pressures required to install the pile with diameter of $250 \mathrm{~mm}$ and those of $500 \mathrm{~mm}$ and $600 \mathrm{~mm}$ might be caused by softening of soil around the installed piles in clays. During the process of pile installation, the volume of water that displaced by a pile squeezed out forming unstable mud layer around the pile shaft. The viscosity of the unstable mud layer increases with the volume of water displaced from the soil. Bhushan [11] stated that the larger the viscosity of the unstable mud layer, the lower will be the friction resistance of the pile. Therefore, the penetration pressures recorded from the jacked-in machine to install the piles with diameter of $500 \mathrm{~mm}$ and $600 \mathrm{~mm}$ were lower than those calculated from the CPT, as shown in Figure 2 and Figure 3. In addition, it can also be seen that the penetration pressures required to install piles with diameter of $600 \mathrm{~mm}$ are lower than those with diameter of $500 \mathrm{~mm}$.

Figure 1a and Figure 1b depict the correlation between penetration pressure of the CPT and that of jacked-in for piles with diameter of $250 \mathrm{~mm}$. The penetration pressure at the ground surface was relatively high since it consists of compacted fill material. 


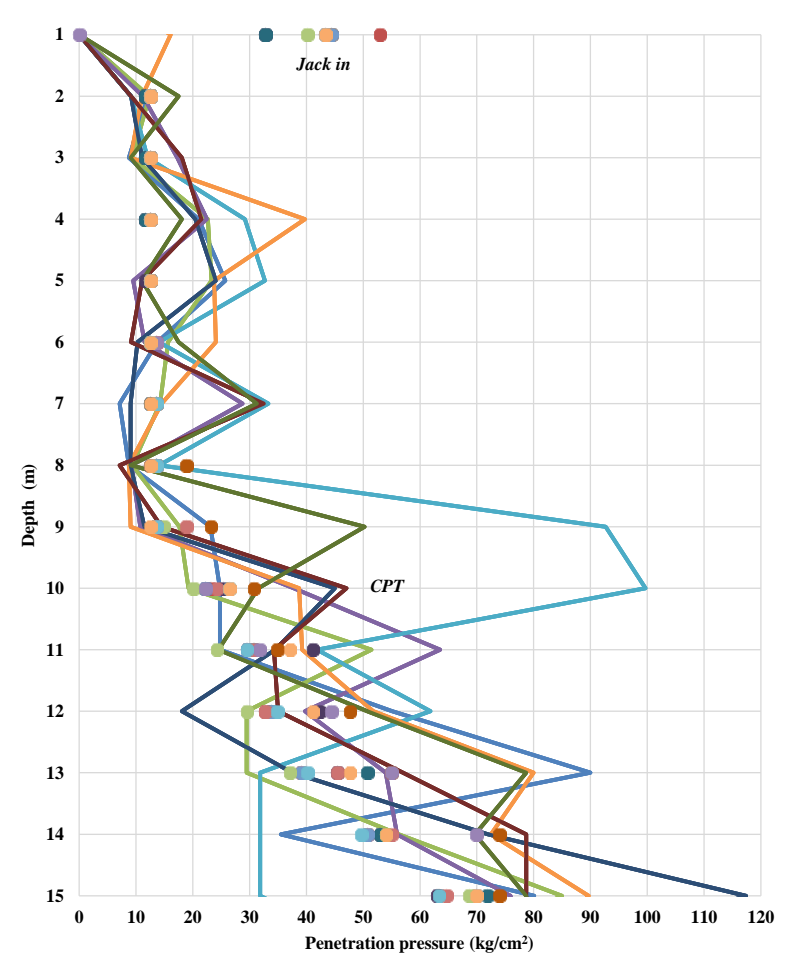

Figure 1a. Penetration Pressures Calculated from CPT and those Recorded from Jacked-in Machine to Install 250 mm Diameter Piles

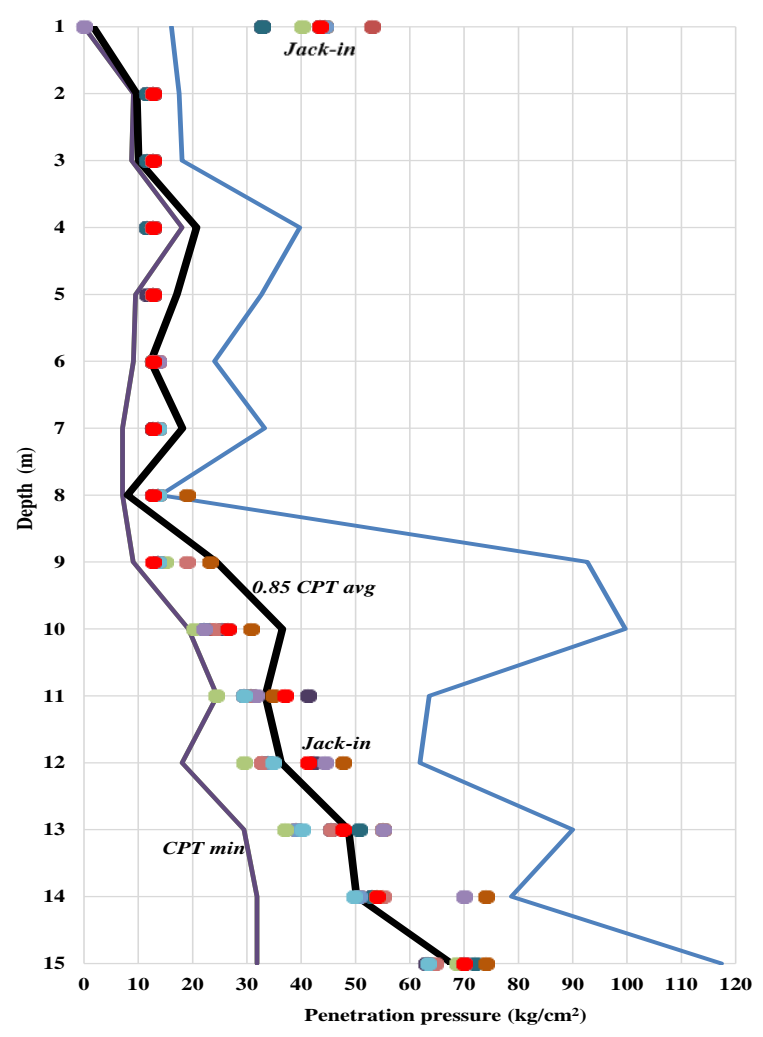

Figure 1b. The Maximum, Minimum, and Factored Mean Penetration Pressures Calculated from CPT and the Recorded Penetration Pressure Required to Install $250 \mathrm{~mm}$ Diameter Piles

The penetration pressure required to penetrate 250 $\mathrm{mm}$ piles is about $85 \%$ of the average pressure calculated from CPT, as shown as curve 0.85 CPT avg in Figure 1b (factored of mean penetration pressures). While the penetration pressure required to install piles with diameter of $500 \mathrm{~mm}$ and $600 \mathrm{~mm}$ is about $65 \%$ of the average penetration pressures calculated from CPT, as shown in Figure $2 \mathrm{~b}$ and Figure 3b, respectively.

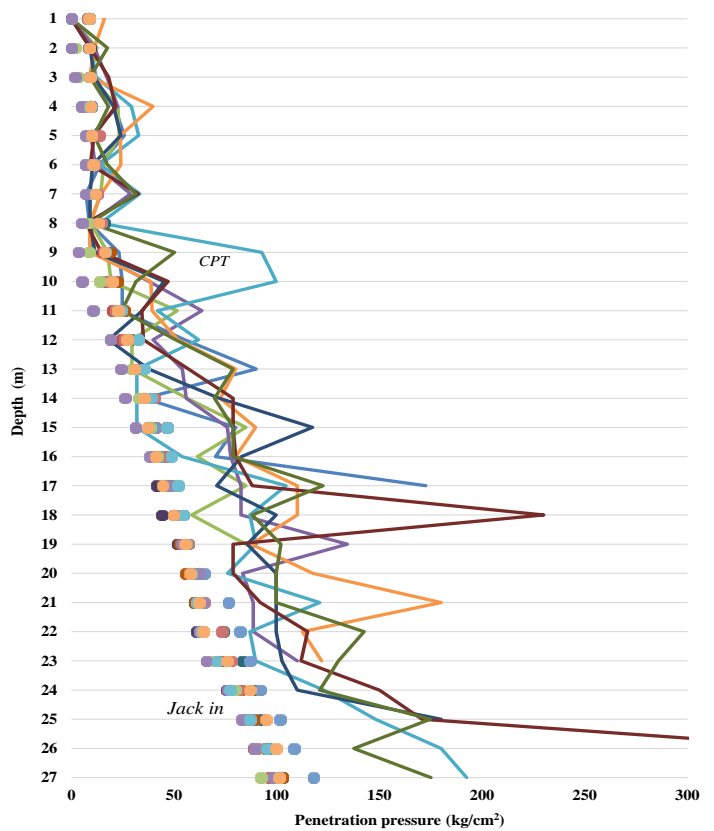

Figure 2a. Penetration Pressures Calculated from CPT and those Recorded from Jacked-in Machine to Install 500 mm Diameter Piles

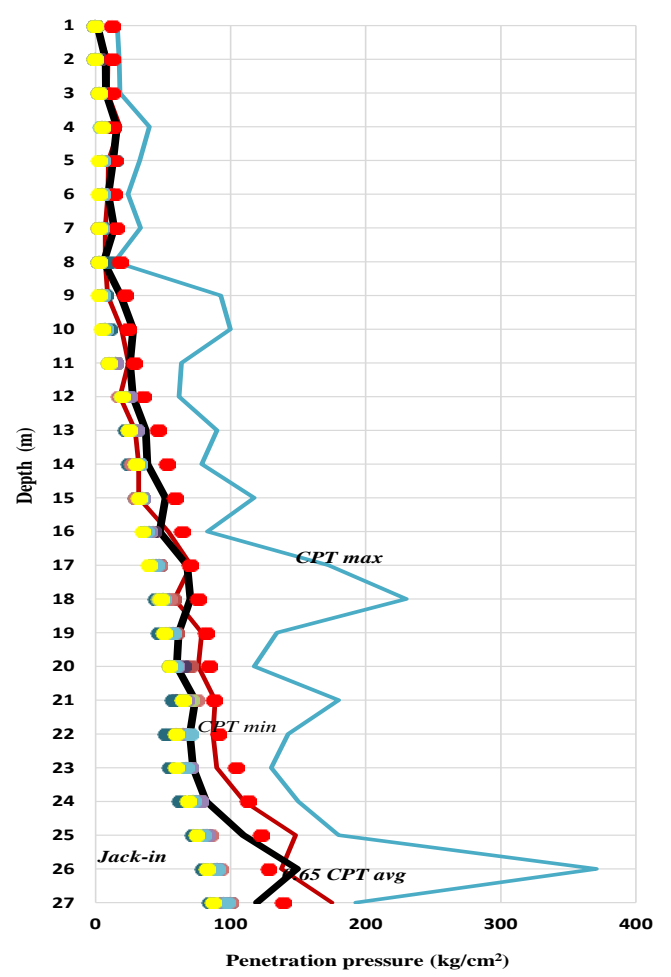

Figure 2b. The Maximum, Minimum, and Factored Mean Penetration Pressures (0.65 CPT avg) Calculated from CPT and the Recorded Penetration Pressure Required to Install 500 mm Diameter Piles 


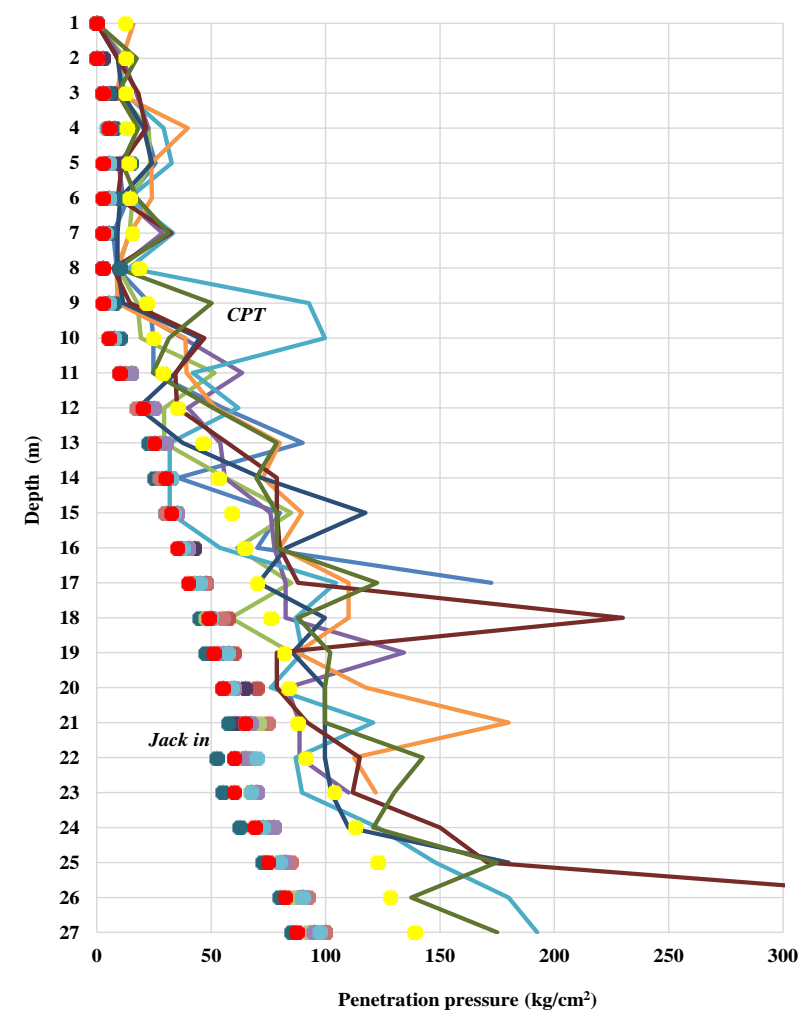

Figure 3a. Penetration Pressures Calculated from CPT and those Recorded from Jacked-in Machine to Install 600 mm Diameter Piles

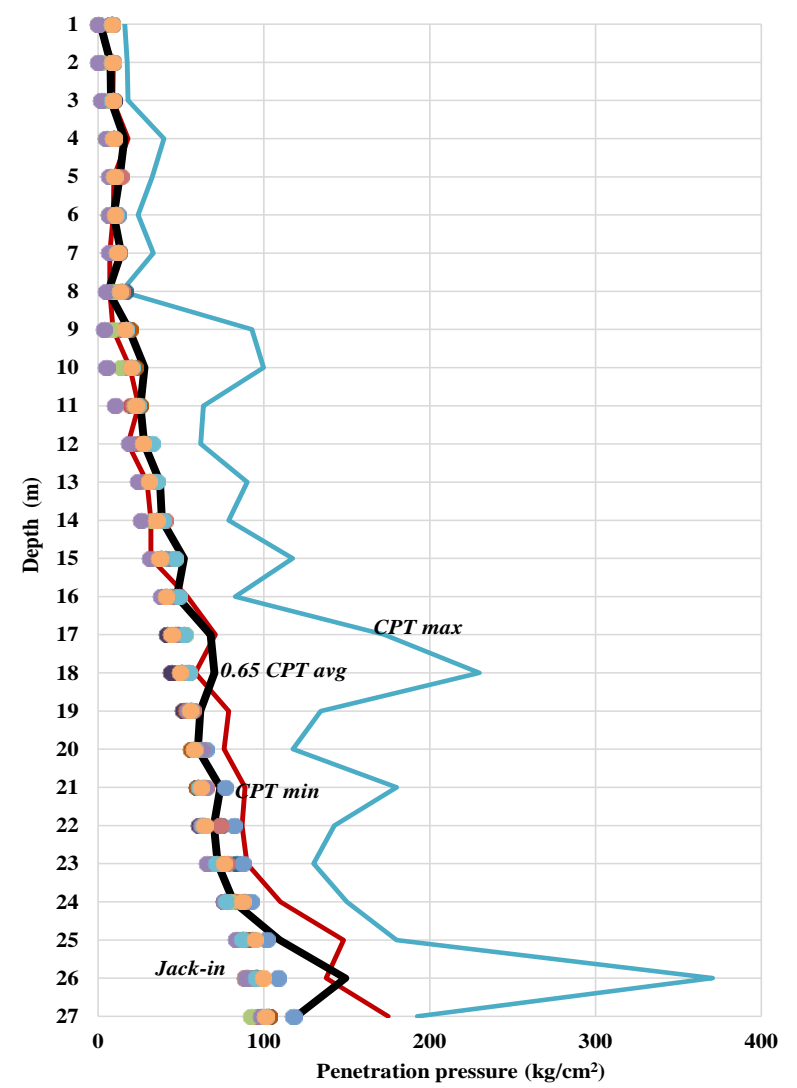

Figure 3b. The Maximum, Minimum, and Factored Mean Penetration Pressures (0.65 CPT avg) Calculated from CPT and the Recorded Penetration Pressure Required to Install 600 mm Diameter Piles

\section{Hydraulically Jacked-in Pile in Very Soft Clay Layer}

Figure 4 shows the correlation between penetration pressure calculated from $\mathrm{CPT}$ and that required to install $600 \mathrm{~mm}$ piles into the $15 \mathrm{~m}$ thick of very soft clay layer underline by stiff clay. It shows that both penetration pressures in the upper part (from ground surface to the depth about $14 \mathrm{~m}$ ) is quite the same, and then it begins to separate one and another where the penetration pressure calculated from CPT is larger than that recorded from jacked-in machine.

When a shaft is penetrated into a very soft clay layer, the volume of clay (and water) that displaced by the pile 'flows' in horizontal and vertical directions. In other words, no unstable mud layer around the pile is formed since there is no increase of water content in the surounding soil. Therefore, the penetration pressure generated due to the pile installation is independent of the pile shaft. While in the deeper layer (below $14 \mathrm{~m}$ ) that consists of stiff clay, the penetration pressure required to install the pile is lower than that calculated from CPT since the water displaced by the piles is squeezed out to form unstable mud layer around the periphery of the pile, which resulting a lower friction. The penetration pressure required to install a pile into lower layer (stiff clay) can be predicted as $65 \%$ of the average of penetration pressure calculated from CPT (Figure 4b)

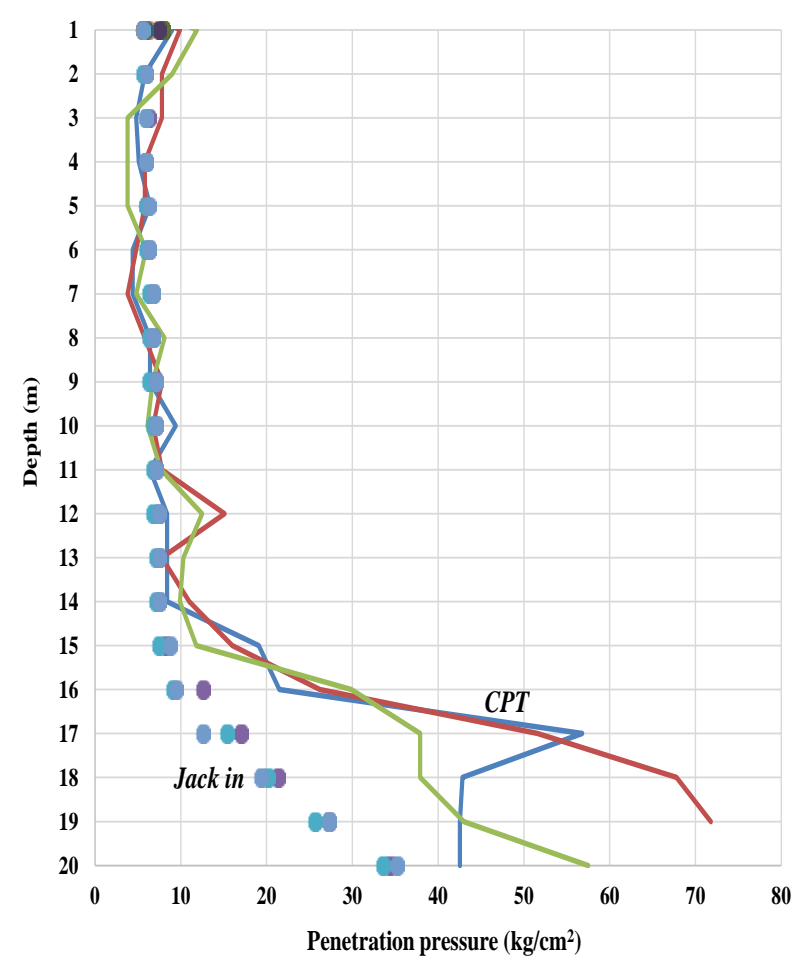

Figure 4a. Penetration Pressures Calculated from CPT and those Recorded from Jacked-in Machine to Install 500 mm Diameter Piles 


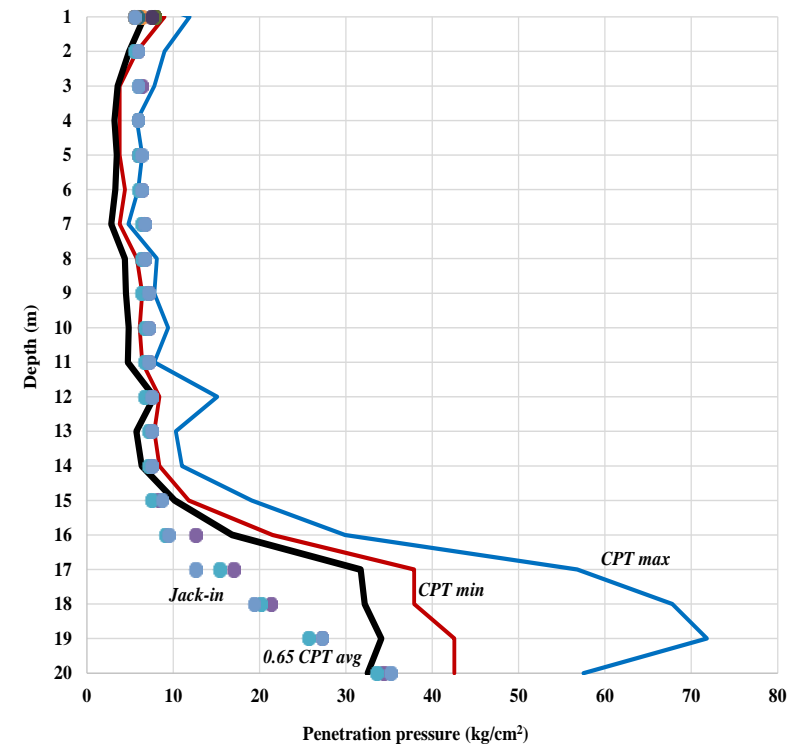

Figure 4b. Penetration Pressures Calculated from CPT and that Recorded from Jacked-in Machine to Install 500 mm Diameter Piles

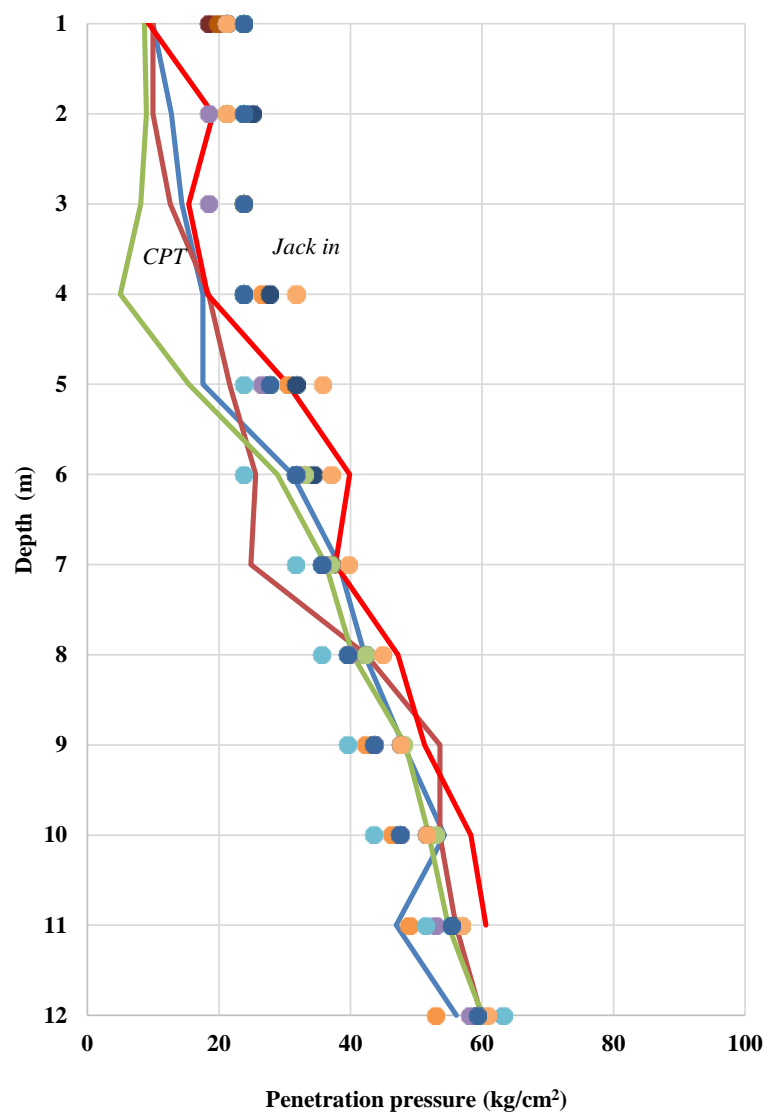

Figure 5a. Penetration Pressures Calculated from CPT and those Recorded from Jacked-in Machine to Install 500 mm Diameter Piles

\section{Hydraulically Jacked-in Pile in Expansive Clay Layer}

Figure 5 show the correlation between penetration pressure calculated from CPT and that required to install $500 \mathrm{~mm}$ piles into $12 \mathrm{~m}$ thick of expansive stiff clay layer (stiff clay). It can be observed from Figure 5a that the penetration pressure recorded from the jacked-in machine to install $500 \mathrm{~mm}$ diameter pile into $5 \mathrm{~m}$ thick of expansive clay is larger than that calculated from CPT. This condition is categorized as strengthen-type [9]. While the correlation of the penetration pressure at the depth of $5 \mathrm{~m}$ to $12 \mathrm{~m}$ is considered as close-type, as shown in Figure 5b. As reported by Testana Engineering [12], the depth of active zone (defined as the depth of upper layer that influenced by the change of water content) in the area of the project is $5 \mathrm{~m}$. The depth of the active zone is quite similar to that along the strengthen-type segmen as shown in Figure 5a. The strengthen-type might be caused by the increase of density of expansive clay (in dry state) due to pile installation. In other words, the friction between pile shaft and surrounding soil increases as the desity of soil increases.

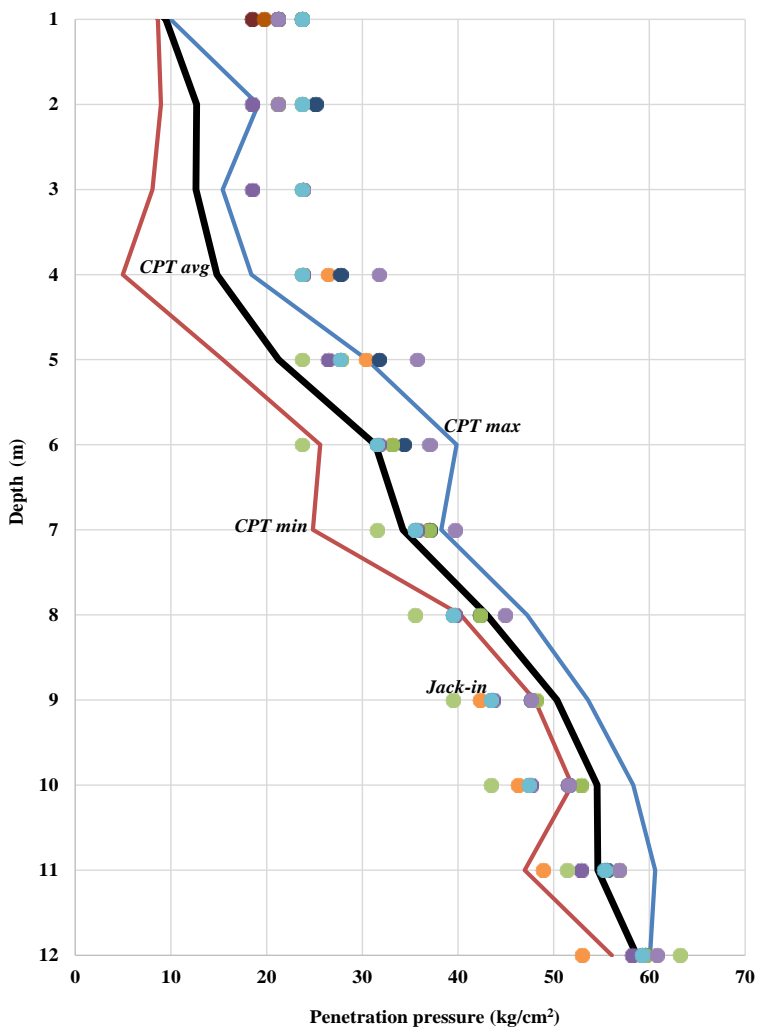

Figure 5b. Penetration Pressures Calculated from CPT and that Recorded from Jacked-in Machine to Install 500 mm Diameter Piles

\section{Conclusion}

Based on the limited data, the initial study shows that:

- The penetration pressure required to install the pile into very soft clay layer is independent of pile diameter since the displaced volume of clay 'flows' outward, which does not form unstable mud layer around the pile. 
- The penetration pressure required to install the pile into soft to stiff clay layers depends on the pile diameter. The larger the diameter of piles, the smaller the penetration pressures required. The penetration pressure needed to install piles with diameter of $250 \mathrm{~mm}$ and $500 \mathrm{~mm}$ can be predicted as $0.85 \mathrm{CPT}$ average and $0.65 \mathrm{CPT}$ average, respectively.

- The penetration pressure required to install the pile into stiff expansive clay layer up to the depth of active zone is in strengthen-type. While the penetration pressure required to install $500 \mathrm{~mm}$ diameter of pile can be predicted as high as the pressure calculated form CPT average.

\section{References}

1. Bogaert, H., History of Cone Penetration Testing $(C P T)$, Translation of the Handboek Geotechnisch Bodemonderzoek Ondergrond, The Vereniging Ondernemers Technisch Bodemonderzoek (VOTB), 2016.

2. White, D. J. and Deeks, A. D., Recent Research into the Behaviour of Jacked Foundation Piles, Cambridge University Engineering Department, UK, 2007.

3. Lehane, B. M., Pennington, D., and Clark, S., Jacked End bearing Piles In The Soft Alluvial Sediments of Perth, Australian Geomechanics, 38(3), 2003, pp. 123-133.
4. Mahler, A., Use of Cone Penetration Test in Pile Design, Periodica Polytechnica Civil Engineering, 47(2), 2003, pp. 189-197.

5. DIN, Deutsches Institut fur Normung (DIN 4014), Bohrpfähle-Herstellung, Bemessung und Tragverhalten, German Association for Earthworks and Foundation Engineering, 1990.

6. Bustamante, M. and Gianeselli, L., Pile Bearing Capacity Prediction by Means of Static Penetrometer CPT, Proceedings of the 2nd European Symposium on Penetration Testing, ESOPT II, Amsterdam, 2, 1982, pp. 493-500.

7. Eurocode 7: Geotechnical Design-Part 3: Design by Field Testing; European Committee for Standardization, 1999.

8. De Cock, F and Legrand, C. editors, Design of Axially Loaded Piles, European Practice, 1997.

9. Hu, Y., Tang, L., Li, Z., and Sang, H., Timerelated Increase Evaluation in Bearing Capacities of End Bearing Jacked Piles by a New Method of CPT, Computer Modelling and New Technologies (12D), 18, 2014, pp. 103-109.

10. SNI 2827:2008. Cara Uji Penetrasi Lapangan dengan Alat Sondir, Badan Standarisasi Nasional, Jakarta, 2008 (in Indonesian).

11, Bhushan, B., Introduction to Tribology, John Wiley \& Son, New York, 2013.

12. Testana Engineering, Soil Investigation Report, January, 2015. 